\title{
Kekerabatan Bahasa Angkola, Bahasa Simalungun dan Bahasa Toba
}

\author{
Siti Rahmadani Lestari Ritonga ${ }^{1}$, Dardanila ${ }^{2}$, Gustianingsih ${ }^{3}$ \\ e-mail: ${ }^{1}$ rahmadanilestari02@gmail.com, ${ }^{2}$ dardanila@usu.ac.id, ${ }^{3}$ gustianingsih@usu.ac.id \\ ${ }^{1,2,3}$ Program Studi Linguistik, Program Pasca Sarjana Fakultas Ilmu Budaya, \\ Universitas Sumatera Utara
}

\begin{abstract}
Abstrak
Penelitian ini bertujuan untuk kekerabatan bahasa Angkola, bahasa Simalungun, dan bahasa Toba. Penelitian ini menggunakan metode kuantitatif dengan analisis data leksikostastik dan glotokronologi. Metode pengumpulan data yang digunakan berupa metode wawancara dan simak dengan teknik sadap dan teknik rekam. Data yang digunakan dalam penelitian ini adalah kosakata dasar yang berisi daftar 200 kosakata Swadesh. Sumber data penelitian ini berupa bentuk lisan dan tulisan bersumberkan langsung dari hasil wawancara penutur. (1) Kekerabatan antara bahasa Angkola dan bahasa Simalungun terdapat 85 pasangan identik, 30 pasangan berkorespondensi fonemis, 5 pasangan mirip secara fonetik, dan 3 pasangan dengan satu fonem berbeda. (2) Kekerabatan antara bahasa Angkola dan bahasa Toba terdapat 106 pasangan identik, 18 pasangan berkorespondensi fonemis, 4 pasangan mirip secara fonetik dan 3 pasangan dengan satu fonem berbeda. (3) Kekerabatan antara bahasa Simalungun dan bahasa Toba terdapat 78 pasangan identik, 28 pasangan berkorespondensi fonemis, 2 pasangan mirip secara fonetik, dan 5 pasangan dengan satu fonem berbeda.
\end{abstract}

Kata kunci_kekerabatan Bahasa, Bahasa Angkola, Bahasa Simalungun, Bahasa Toba

\section{A. PENDAHULUAN}

Berbagai bahasa jika dilihat berdasarkan sejarahnya, apalagi hidup dalam komunitas yang berdekatan secara geografis maka akan memiliki kesamaan satu dengan yang lain. Dalam Linguistik kajian-kajian tentang perbandingan bahasa dari sisi sejarahnya disebut kajian Linguistik Historis Komparatif.

Dalam Linguistik Historis Komparatif dipelajari data-data dari suatu bahasa atau lebih, sekurang-kurangnya dalam dua periode. Data-data itu diperbandingkan dengan cara cermat untuk memperoleh kaidah-kaidah perubahan yang terjadi dalam bahasa tersebut (Keraf, 1984:22). Linguistik Historis Komparatif dikenal juga dengan Linguistik Diakronis, yang berupaya mengkaji bahasa dalam kurun waktu yang berbeda. Hal ini berlawanan dengan Linguistik Sinkronis, yang berupaya mempelajari bahasa dalam kurun waktu yang sama. Menurut Robins (1990) linguistik diakronis yang termasuk Cabang linguistik ini 
memberi kontribusi berharga bagi pemahaman tentang hakikat kerja bahasa dan perkembangan bahkan perubahan bahasa-bahasa pada umumnya.

Pada dasarnya, perubahan bahasa merupakan suatu fenomena yang bersifat semesta dan universal. Perubahan bahasa sebagai fenomena yang bersifat umum dapat dilihat dari perubahan bunyi pada tataran fonologi yang merupakan tataran kebahasaan yang sangat mendasar dan penting dalam rangka telaah di bidang Linguistik Historis Komparatif (Fernandes, 1996). Perubahan yang dimaksud tidak terlepas dari pembicaraan beberapa bahasa yang berbeda tetapi masih dalam rumpun yang sama atau bahasa yang sama tetapi dalam kurun waktu yang berbeda.

Bahasa Angkola, bahasa Simalungun dan bahasa Toba adalah bahasa yang tergolong dalam keluarga bahasa Austronesia yang dituturkan oleh masyarakat di Pulau Sumatera bagian utara. Suku Batak adalah suatu suku yang tinggal di Provinsi Sumatera Utara. Secara geografis di Provinsi Sumatera Utara, suku Batak terdiri atas 5 etnis, yaitu Batak Toba (Tapanuli), Batak Simalungun, Batak Karo, Batak Mandailing (Angkola), dan Batak Pakpak (Dairi) yang memiliki bahasa yang berbeda-beda. (Hutabarat, Ermanto, \& Juita, 2013: 2) Dalam penelitian ini objek yang akan dibahas adalah bahasa Angkola, bahasa Simalungun, dan bahasa Toba yang selanjutnya akan disebut BA, BS, dan BT.

Ketiga bahasa ini dijadikan objek penelitian karena berada di wilayah tutur yang berdekatan (letak geografis yang berdekatan), sehingga secara geografi tentu memiliki kesamaan yang lebih besar dibandingkan dengan bahasa-bahasa yang letak geografi pemakainya yang berjauhan. Selain itu, dilakukannya penelitian ini berkaitan dengan kurangnya penelitian terhadap bahasa-bahasa Batak dari segi geneologis (genetis) yang dapat mengelompokkan bahasa-bahasa serumpun yang dibuktikan dari variasi konsep-konsep mengenai apakah bahasa-bahasa di wilayah geografis etnis Batak termasuk bahasa tersendiri atau hanya dialek (Panggabean, 2012:2). Oleh karena itu, mengetahui silsilah kekerabatan, waktu pisah dan perkiraan usia tiga bahasa ini penting untuk diketahui dalam upaya pengembangan bahasa daerah di Indonesia dan ilmu pengetahuan bahasa dalam bidang linguistik historis komparatif. Beberapa contoh di bawah ini akan menggambarkan persamaan dan perbedaan kosakata dalam ketiga bahasa yang menjadi objek penelitian.

Tabel 1.1 Contoh kosakata dalam bahasa Angkola, Simalungun dan Toba

\begin{tabular}{lllll}
\hline PAN & Angkola & Simalungun & Toba & Gloss \\
\hline *aabu & abu & abu & orbuk & abu \\
\hline *‘apa' & aha & aha & aha & apa \\
\hline *hucap & manecet & hata & hata & berkata
\end{tabular}

Keterangan : PAN: Proto-Austronesia 
Data di atas menunjukkan bahwa ketiga bahasa ini memiliki persamaan dan perbedaan sebagai bahasa yang berada dalam wilayah geografis yang berdekatan. Dalam bahasa Angkola, Toba dan Simalungun kata 'apa' tidak berbeda bunyi. Namun pada kata 'abu' terdapat perubahan bunyi pada bahasa Toba. Kemudian pula pada kata 'berkata,' terlihat terjadi perbedaan dalam ketiga bahasa dari bentuk Proto-Austronesianya. Dalam bahasa Toba dan Simalungun tidak berbeda jauh (hata), tetapi dalam bahasa Angkola berbeda (Majecet). Dalam membahas kekerabatan ketiga bahasa, indikator yang akan digunakan untuk melihat silsilah atau kekerabatan bahasa ini adalah kosakata dasar Swadesh dengan pertimbangan bahwa daftar Swadesh merupakan daftar yang paling banyak dijadikan acuan untuk mempelajari kekerabatan bahasa-bahasa di dunia. Kosakata dasar Swadesh yang dijadikan acuan penelitian berjumlah 200 kosakata, merupakan kosakata yang digunakan secara universal di dunia. Artinya, kosakata ini ada pada seluruh penduduk dunia dan kemungkinan tidak berubah dalam kurun waktu yang lama.

Penelitian terkini yang terkait bahasa Angkola, Simalungun dan Toba dalam tinjauan historis komperatif beberapa telah dilakukan. Antara lain penelitian Mualita (2015) yang membahas tentang kekerabatan bahasa Toba dan bahasa Angkola. Dari hasil penelitiannya menyimpulkan bahwa bahasa Angkola dan bahasa Toba dikategorikan dalam kekerabatan dengan hasil perhitungan kemiripan $57 \%$ dan tahun pisah kedua bahasa berkisar pada tahun 681 M. Penetian lain dilakukan oleh Fitrah \& Afria (2017) yang membahas tentang bahasa etnis Melayu, Batak, Sunda dan Jawa di provinsi Jambi. Dalam penelitiannya bahasa Batak yang dimaksud adalah bahasa masyarakat etnis Batak yang tinggal di provinsi Jambi.

Dari beberapa penelitian terdahulu di atas, dapat diketahui bahwa adanya kekerabatan dari bahasa Angkola, Mandailing dan Toba. Namun penelitian sebelumnya seperti yang dilakukan oleh Maulita (2015) hanya sebatas pada perbandingan dua bahasa. Berbeda dalam penelitian ini yang akan membandingkan tiga bahasa. Kemudian terdapat penelitian Fitrah \& Afria (2017) mengenai kekerabatan bahasa-bahasa etnis Melayu, Batak, Sunda, Bugis, dan Jawa di provinsi Jambi. Namun penelitian Fitrah \& Afria (2017) hanya membahas perbandingan bahasa dalam lingkungan penutur etnis tertentu di tempat bukan dari bahasa tersebut berasal (Jambi). Berbeda dengan penelitian ini yang mengkaji bahasa satu etnis (Batak) di tempat asal etnis tersebut. Oleh karena itu, penelitian ini dilakukan sebagai penelitian lanjutan dari penelitian-penelitian sebelumnya mengenai kekerabatan bahasa masyarakat etnis Batak Angkola, Simalungun dan Toba dengan pendekatan kajian Linguistik Historis Komparatif (LHK).

Penelitian ini juga diharapkan dapat memberikan kontribusi dalam perspektif baru tentang teori kekerabatan, khususnya yang terkait dengan ketiga bahasa yang dianalisis dalam penelitian ini. Mengacu pada berbagai fenomena yang telah dijelaskan sebelumbya, maka dalam penelitian ini dibahas relasi kekerabatan bahasa Angkola, bahasa Simalungun, dan bahasa Toba. 


\section{B. KAJIAN TEORI}

\section{Kata Kerabat}

Keraf (1984: 127) mengemukakan ada empat langkah penetapan kata kerabat. Sepasang bahasa akan dikatakan berkerabat apabila memenuhi salah satu indikator kekerabatan tersebut. Empat jenis penetapan kata kerabat dikemukakan oleh Keraf adalah sebagai berikut.

a. Pasangan identik

Pasangan kata identik adalah pasangan kata yang semua fenomenanya sama betul, misalnya:

\begin{tabular}{llll}
\hline Angkola & Simalungun & Toba & Gloss \\
\hline bulan & bulan & bulan & bulan \\
\hline dua & dua & Dua & dua \\
\hline
\end{tabular}

b. Korespondensi fonemis

Perubahan fonemis antara kedua bahasa itu terjadi secara timbal-balik dan teratur, serta tinggi frekuensinya, maka bentuk yang berimbang antara kedua bahasa tersebut dianggap berkerabat.

Contohnya:

\begin{tabular}{llll}
\hline Angkola & Simalungun & Toba & Gloss \\
\hline marlaye & marlayei & marlaye & berenang \\
\hline api & apui & api & api
\end{tabular}

c. Satu fonem berbeda

Bila dalam satu pasangan kata terdapat perbedaan satu fonem, tetapi dapat dijelaskan bahwa perbedaan itu terjadi karena pengaruh lingkungan yang dimasukinya. Sedangkan dalam bahasa lain pengaruh lingkungan itu tidak mengubah fonemnya, maka pasangan itu dapat ditetapkan sebagai kata kerabat asal segmennya cukup panjang. 


\begin{tabular}{cccc}
\hline Angkola & Simalungun & Toba & Gloss \\
\hline minum & inum & inum & minum \\
\hline ipon & ipən & ipon & gigi \\
\hline
\end{tabular}

\section{Kekerabatan Bahasa}

Bahasa yang berkerabat adalah bahasa yang memiliki hubungan antara satu dengan lainnya. Hubungan ini merupakan asal dari induk yang sama sehingga terdapat kemiripan atau adanya ciri-ciri umum yang sama. Kemiripan bahasa ini terutama terlihat dari segi fonologisnya atau mungkin morfologi bahkan sintaksisnya (Keraf, 1984). Adapun penjelasan lain mengenai kekerabatan (geneticrelationship) dipahami sebagai hubungan antara dua bahasa atau lebih yang diturunkan dari sumber ataupun rumpun bahasa induk yang sama, disebut sebagai bahasa purba (Kridalaksana, 2008:116; Al-Khuli, 1982:105).

\section{Rumpun Protobahasa Austronesia}

Protobahasa Austronesia adalah istilah yang diberikan oleh ahli linguistik, untuk menyebut suatu rumpun bahasa yang hampir dituturkan oleh semua orang di kepulauan IndoMalaysia dan Oceania. Pada akhirnya istilah Austronesia juga digunakan untuk menyebut suatu bangsa yang menggunakan rumpun bahasa tersebut. Rumpun bahasa Austronesia terdiri dari 1.200 bahasa dan digunakan oleh kira-kira 270 juta penutur (Bellwood, J.Fox, Tryon dkk, 1995:1). Rumpun Austronesia dengan sub-rumpun dan turunannya itu tersebar dengan wilayah terluas dari Madagaskar sampai ke pulau paskah, dari Taiwan-mikronesia hingga Selandia Baru (Mbete, 2016:2).

\section{Sistem Bunyi Proto Austronesia}

Bahasa merupakan suatu sistem lambang bunyi yang hampir tidak ada kegiatan sebuah bahasa dari sistem lambang bunyi tersebut. Hal ini juga berlaku pada bahasa proto Austronesia. Sekalipun bahasa ini tergolong bahasa tua dan telah menurunkan bahasa yang ada dalam rumpun bahasa tersebut. Proto Austronesia telah memiliki sistem tersendiri, baik dari pembendaharaan bunyi vokal dan konsonan serta distribusinya namun ada pula persamaan apabila bahasa itu dianggap seasal dan seketurunan dengan bahasa-bahasa lainnya.

Maksud dari persamaan tersebut adalah bahwa setiap sistem bunyi bahasa mana pun pasti memiliki dua golongan yang disebut fonem-fonem segmental dan suprasegmental. Bunyi segmental terdiri atas konsonan dan vokal yang jumlah distribusinya berbeda-beda pada setiap bahasa. Perbedaan itu sebagai adanya tanda perubahan, berlaku atas bahasabahasa yang dianggap seasal. Demikian pula unsur suprasegmental (tekanan, nada, pemanjangan) terdapat pada setiap bahasa. Hal-hal dan unsur yang sama dan berbeda itu berlaku pula atas bahasa-bahasa Austronesia. 


\section{Sistem Bunyi Fonem Vokal Proto Austronesia}

Blust (2013), fonem vokal bahasa proto Austronesia ada empat buah yaitu */i/, */u/, */ə/, dan */a/. Untuk lebih jelas, dapat dilihat pada tabel berikut ini.

Tabel 1. Peta fonem vokal PAN

\begin{tabular}{llll}
\hline Posisi Lidah & Depan & Tengah & Belakang \\
& Tak bundar & Tak bundar & Bundar \\
\hline Tinggi & $*_{\mathrm{i}}$ & & $*_{\mathrm{u}}$ \\
\hline Sedang & & $*_{\partial}$ & \\
\hline Rendah & & $*_{\mathrm{a}}$ & \\
\hline
\end{tabular}

Sumber (Blust, 2013: 51)

\section{Tipe- tipe Perubahan Bunyi}

Penentuan kata yang berkerabat sering kali terjadi kesulitan ketika seorang peneliti tidak memahami dengan baik bentuk-bentuk perubahan bunyi yang muncul secara sporadis. Kata sporadis diartikan sebagai perubahan yang tidak teratur. Tipe-tipe perubahan bunyi yang tidak teratur tersebut dipahami dari kosa kata dasar yang pada awalnya sama. Berkaitan dengan perubahan bunyi, semua ahli seperti Crowley (2010), dan Keraf (1984) sependapat mengenai pengertian dari tipe-tipe perubahannya, baik dari asimilasi, disimilasi, penambahan bunyi, penghilangan bunyi, ataupun perubahan berdasarkan tempat (metatesis).

\section{Asimilasi}

Asimilasi merupakan suatu proses perubahan bunyi ketika dua fonem yang berbeda dalam bahasa proto mengalami perubahan menjadi fonem yang sama dalam bahasa sekarang atau proses perubahan satu segmen (bunyi) menjadi serupa dengan yang lainnya. Asimilasi disebut asimilasi total atau identik, dan ada juga yang disebut asimilasi parsial atau sebagian saja. Asimilasi total atau identik terjadi apabila perubahan secara total atau seluruhnya, sedangkan asimilasi parsial terjadi apabila perubahan terjadi hanya sebagian ciri-ciri fonetis bunyi-bunyi tersebut yang disamakan. Misalnya dalam bahasa Angkola telah ditemukan asimilasi seperti contoh berikut: kata /sempit/ dalam gloss mengalami perubahan pada bahasa batakAngkola dan bahasa Simalungun menjadi /soppit/ sedangkan dalam bahasa batak Toba menjadi /sompit/, asimilasinya /mp/ menjadi /pp/.

\section{Disimilasi}

Disimilasi merupakan kebalikan dari asimilasi. Jika asimilasi merupakan perubahan yang tidak sama menjadi sama, dalam disimilasi perubahan bunyi terjadi dari yang sama menjadi tidak sama. Kata /sakit/ dalam gloss mengalami perubahan pada bahasa batak Angkola menjadi /hancit/ yang disimilasinya menjadi /haccit/. 


\section{Perubahan Bunyi Berdasarkan Tempat}

Perubahan bunyi berdasarkan tempat merupakan perubahan bunyi yang berkaitan dengan perubahan letak bunyi-bunyi bahasa. Perubahan letak bunyi-bunyi ini akan menghasilkan kata-kata yang berbeda tetapi masih berada dalam lingkup makna yang sama. Berdasarkan tempatnya diperoleh beberapa macam perubahan bunyi (Keraf, 1984: 90-92) adalah:

a. Metatesis merupakan suatu proses perubahan bunyi yang berujud pertukaran tempat pada fonem.

b. Aferesis merupakan penghulangan bunyi vokal/konsonan pada awal kata.

c. Sinkop merupakan penghilangan sebuah bunyi ditengah kata.

d. Apokop merupakan penghilangan bunyi di akhir kata.

e. Protesis adalah penambahan bunyi vokal/konsonan di awal kata.

f. Epentesis adalah penambahan vokal di tengah kata untuk memisahkan dua konsonan dalam sebuah kluster.

g. Paragog merupakan penambahan sebuah bunyi vokal/konsonan di akhir kata.

Berbeda dengan Keraf, beberapa linguis lainnya mengelompokkan tipe-tipe perubahan bunyi berdasarkan penghilangan vokal/konsonan dan penambahannya, lihat (Crowley, 2010: 26-32; Campbell, 1999: 25-31). Adapun penghilangan yang dimaksudkan itu seperti (apheresis, apocope, sincope, clusterreduction dan haplology). Sedangkan metathesis dikelompokkan dalam perubahan-perubahan bunyi yang lain.

\section{Leksikostatistik}

Crowley (2010: 137) menjelaskan leksikostatistik merupakan suatu teknik untuk menentukan tingkat hubungan antara dua bahasa, dengan membandingkan kosakata dan menentukan kesamaan antara kedua bahasa. Sependapat dengan tersebut Keraf (1984: 121) menjelaskan bahwa leksikostatistik adalah suatu teknik dalam pengelompokkan bahasa yang lebih cenderung mengutamakan peneropongan kata-kata secara statistik dan kemudian berusaha menetapkan pengelompokkan itu secara statistik dan kemudian berusaha menetapkan pengelompokkan itu berdasarkan persentase kesamaan dan perbedaan suatu bahasa dengan bahasa lain.

Ada empat macam asumsi dasar yang dapat dipergunakan sebagai tolak ukur dalam mencari jawaban mengenai usia bahasa, atau secara tepatnya bilaman terjadi diferensiasi antara dua bahasa atau lebih (Keraf, dalam Hanna, Mursidin, \& Jannah, 2018). Asumsiasumsi tersebut adalah:

a. Sebagian dari kosa kata suatu bahasa sukar sekali berubah bila dibandingkan dengan bagian lainnya. 
Kosa kata yang sukar berubah dalam asumsi dasar adalah kosa kata dasar yang merupakan unsur-unsur yang menentukan mati hidupnya suatu bahasa. Kosakata dasar itu meliputi (1) kata ganti; (2) kata bilangan; (3) kata-kata mengenai anggota badan (sifat atau aktivitasnya); (4) alam dan sekitarnya, (5) alat-alat perlengkapan sehari-hari yang sudah ada sejak permulaan: tongkat, pisau, rumah dan sebagainya.

Morris swadesh mengusulkan sekitar 200 kosakata dasar yang dianggapnya universal, artinya kosakata dasar tersebut terdapat pada bahasa diseluruh dunia.

\section{b. Retensi (ketahanan) kosakata dasar adalah konstan sepanjang masa}

Asumsi dasar kedua yang mengatakan bahwa dari kosa kata dasar yang ada dalam suatu bahasa, suatu persentase tertentu selalu akan bertahan dalam 1.000 tahun. Kalau asumsi ini diterima, maka dari sebuaha bahasa yang memiliki 200 kosa kata, sesudah 1.000 tahun akan bertahan 80,5\%, dan dari sisanya sesudah 1.000 tahun kemudian akan bertahan lagi dalam persentase yang sama.

\section{c. Perubahan kosa kata dasar pada semua bahasa adalah sama}

Setelah menguji beberapa bahasa dengan asumsi dasar ketiga ini, hasilnya akan menunjukkan bahwa dalam tiap 1.000 tahun, kosakata dasar suatu bahasa bertahan dengan angka rata-rata 80,5\%. Apabila kita ingin menghitung retensi (ketahanan) kosakata dasar kedua bahasa dengan mempergunakan asumsi dasar kedua, dapat dinyatakan dengan rumus: $80.5 \%$ x N. N adalah jumlah kosa kata dasar yang pada awal kelipatan 1000 tahun kedua bahasa. Sehingga, dari 200 kosa kata dasar (N) suatu bahasa, sesudah 1000 tahun pertama akan tinggal $80.5 \%$ x $200=161$ kata, sesudah 1000 tahun kedua akan tinggal $80.5 \%$ x $161=139,6$ kata atau dibulatkan menjadi 140 kata. Selanjutnya sesudah 1000 tahun ketiga kosakata dasar yang tinggal adalah 80. 5\% x 140 $=112,7$ kata atau dibulatkan menjadi 113 kata dan seterusnya (seperti yang dijabarkan oleh Crowlley di atas).

d. Bila persentase dari dua bahasa kerabat (cognate) diketahui, maka dapat dihitung waktu pisah kedua bahasa tersebut.

Berdasarkan asumsi dasar kedua, ketiga dan keempat, kita dapat menghitung usia atau waktu pisah bahasa-bahasa yang diteliti kalau diketahui persentase kata kerabat kedua bahasa itu. Karena dalam tiap 1000 tahun kedua bahasa kerabat masing-masing akan kehilangan kosa kata dasarnya dalam persentase yang sama, maka waktu pisah dalam kedua bahasa itu harus dibagi dua. Misalnya persentase kata kerabatnya adalah 80 , 5\%, maka waktu pisah kedua bahasa adalah 500 tahun yang lalu.

\section{METODE PENELITIAN}

Penelitian ini menggunakan metode deskriptif kuantitatif. Metode kuantitatif yaitu menggunakan perhitungan yang disebut leksikostatistik untuk menentukan tingkat kekerabatan bahasa yan diteliti. 
Metode perbandingan juga digunakan untuk membandingkan persamaan dan perbedaan bunyi antar ketiga bahasa. Perbandingan dilakukan antara bahasa Angkola dengan bahasa Simalungun, bahasa Angkola dengan bahasa Toba dan bahasa Simalungun dengan bahasa Toba guna melihat relasi kekerabatan dengan menemukan persamaan dan perbedaan bahasa-bahasa tersebut. Metode perbandingan merupakan sebuah metode yang merincikan kajian yang disebut Linguistik Historis Komparatif.

Lokasi penelitian yang pertama adalah kabupaten Tapanuli Selatan guna menjaring data bahasa Angkola (BA). Daerah ini merupakan wilayah penutur BA yang mayoritas digunakan di daerah kabupaten ini. Lokasi kedua adalah kabupaten Simalungun yang merupakan tempat paling tepat untuk mengambil data bahasa Simalungun (BS) dan bahasa Toba (BT) karena mayoritas didiami oleh masyarakat pengguna BS dan BT. Berikut data kedua lokasi penelitian. Penelitian dilaksanakan pada awal bulan Oktober 2019, namun peneliti sudah melakukan pengamatan awal untuk mempersiapkan tulisan ini sejak Agustus 2019.

Data yang digunakan dalam penelitian ini adalah kosakata dasar yang berisi daftar 200 kosakata Swadesh yang diperoleh melalui wawancara penutur asli bahasa (BA, BS dan BT). Dua ratus kosakata tersebut dianggap ada di seluruh bahasa yang ada di dunia dan tidak akan berubah dalam kurun waktu selama 1000 tahun.

Sumber data yang digunakan dalam penelitian ini adalah data dalam bentuk lisan dan tulisan. Data dalam bentuk lisan diperoleh peneliti bahasa yang bersumberkan langsung dari hasil wawancara penutur bahasa sebagai fenomena lingual yang kemudian disebut sebagai sumber data primer (Sudaryanto, 2016: 224). Sumber data lisan tersebut berasal dari tiga orang penutur asli dari masing-masing bahasa yang akan diteliti, jadi total jumlah penutur asli ada sembilan orang.

Dalam pengumpulan data digunakan metode cakap dan metode simak. Metode cakap digunakan karena peneliti terlibat langsung dengan informan selaku narasumber. Adapun beberapa teknik yang digunakan dalam metode ini, yaitu: (1) teknik pancing, (2) teknik cakap semuka, (3) teknik cakap taksemuka, teknik ini tidak digunakan karena peneliti menganggap teknik ini merupakan opsional dari teknik sebelumnya, (4) teknik rekam, dan (5) teknik catat.

Metode yang digunakan dalam menganalisis data ini adalah metode perbandingan (Crowlley, 2010: 79-93), yaitu membandingkan kata-kata yang ada dalam BA, BS, dan BT. Pendekatan yang digunakan pada atahapan ini adalah kualitatif, perbandingan ditujukan untuk menentukan tahapan-tahapan dalam menganalisis pewarisan PAN pada ketiga bahasa.

\section{HASIL DAN PEMBAHASAN}

\section{Analisis Relasi Kekerabatan Bahasa Angkola, Bahasa Simalungun, dan Bahasa Toba}

Data yang diambil merupakan data swadesh yang berjumlah 200 kosakata. Kemudian dianalisis untuk mengetahui tingkat kekerabatan dan persentase kerabat antara BA, BS, dan BT. Sebelum menghitung persentase tingkat kekerabatan, maka terlebih dahulu menghitung kosakata yang berkerabat. Dalam menghitung kosa kata berkerabat, peneliti menggunakan 
tanda (+) dan (-). Apabila pasangan kedua bahasa itu berkerabat, maka ditandai dengan kode $(+)$, sebaliknya apabila pasangan kata diantara kedua bahasa itu tidak berkerabat ditandai dengan kode (-). Perhitungan jumlah kata kerabat dapat dilakukan dengan melihat kesamaan penanda antar kata kerabat bahasa tersebut.

Tabel 2. Contoh penyajian data kekerabatan

\begin{tabular}{llllc}
\hline No & Bahasa Angkola & Bahasa Simalungun & Glos & Kekerabatan \\
\hline 1. & $a b u$ & $a b u$ & abu & + \\
\hline 2. & $a E k$ & $a e k$ & air & + \\
\hline 3. & urat & urat & akar & + \\
\hline 4. & $a u$ & $a u$ & aku & +
\end{tabular}

Dst.

Berdasarkan analisis terhadap 200 kosakata yang terdapat pada bahasa Angkola, bahasa Simalungun, dan bahasa Toba diketahui kekerabatan antara bahasa Angkola dan bahasa Simalungun terdapat 85 pasangan identik, 30 pasangan berkorespondensi fonemis, 5 pasangan mirip secara fonetik, dan 3 pasangan dengan satu fonem berbeda. Kekerabatan antara bahasa Angkola dan bahasa Toba terdapat 106 pasangan identik, 18 pasangan berkorespondensi fonemis, 4 pasangan mirip secara fonetik dan 3 pasangan dengan satu fonem berbeda. Kekerabatan antara bahasa Simalungun dan bahasa Toba terdapat 78 pasangan identik, 28 pasangan berkorespondensi fonemis, 2 pasangan mirip secara fonetik, dan 5 pasangan dengan satu fonem berbeda.

Berikut adalah klasifikasi berdasarkan prosedur penetapan kata berkerabat dari ketiga bahasa.

\section{Glos yang Tidak Diperhitungkan}

Gloss yang tidak diperhitungkan merupakan kata-kata kosong, kata serapan atau pinjaman baik dari bahasa kerabat maupun yang tidak berkerabat. Pada analisis ini, tidak ada ditemukannya glos yang tidak diperhitungkan baik pada BA, BS, maupun BT.

\section{Pengisolasian Morfem Terikat}

Morfem terikat dalam data yang didapatkan di lapangan terdapat tiga kosakata, yakni: 
Tabel 3. Data morfem terikat

\begin{tabular}{lllll} 
No & BA & BS & BT & Glos \\
\hline 1. & mayalir & mayalir & mamolus & alir (me) \\
2. & marburu & marburu & mamuru & buru (ber-) \\
3. & manaEk & naik & naik & naik \\
\hline
\end{tabular}

Glos di atas, tidak dapat berdiri sendiri melainkan harus terikat pada morfem yang lain. Dapat dilihat bahwa terdapat imbuhan ma-/mar- di setiap kosakata baik pada BA, BS, maupun BT.

\section{Penetapan Kata Kerabat}

\section{Pasangan Kata Identik}

Salah satu ketentuan dalam menetapkan pasangan kata tersebut sebagai kata kerabat adalah pasangan kata tersebut memiliki kemiripan identik. Identik dalam hal ini adalah pasangan kata tersebut memiliki bentuk, bunyi, dan makna yang sama persis. Adapun data pasangan kata identik sebagai berikut:

Berdasarkan hasil analisis, maka diketahui bahwa kekerabatan antara Bahasa Angkola dan Bahasa Simalungun sebanyak 85 pasang kosakata yang memiliki kesamaan bentuk dan makna. Kemudian diketahui terdapat 78 pasang kosakata yang memiliki kesamaan bentuk dan makna antara Bahasa Simalungun dan Bahasa Toba.

\section{Korespondensi Fonemis}

Pasangan kata yang memiliki korespondensi fonemis merupakan pasangan kata yang memiliki hubungan antara kedua bahasa berdasarkan posisi fonem-fonem dan makna yang sama dari kedua bahasa yang dibandingkan.

Berdasarkan hasil analisis diketahui kekerabatan bahasa antara BA dan BS yang saling berkorespondensi fonemis sebanyak 30 pasang kosakata. Beberapa korespondensi fonemis yang terjadi antara BA dan BS adalah sebagai berikut:

Tabel 4. Analisis Korespondensi Fonemis pada BA dan BS

\begin{tabular}{rll}
\hline No & Korespondensi & Kosakata \\
\hline 1. & $\varnothing=\mathrm{u}$ & api : api $=$ apui \\
\hline $2 . \quad \varnothing=\mathrm{i}$ & berenang : marlaye $=$ marlayei \\
& & dengar : mambege $=$ mambegei \\
\hline
\end{tabular}




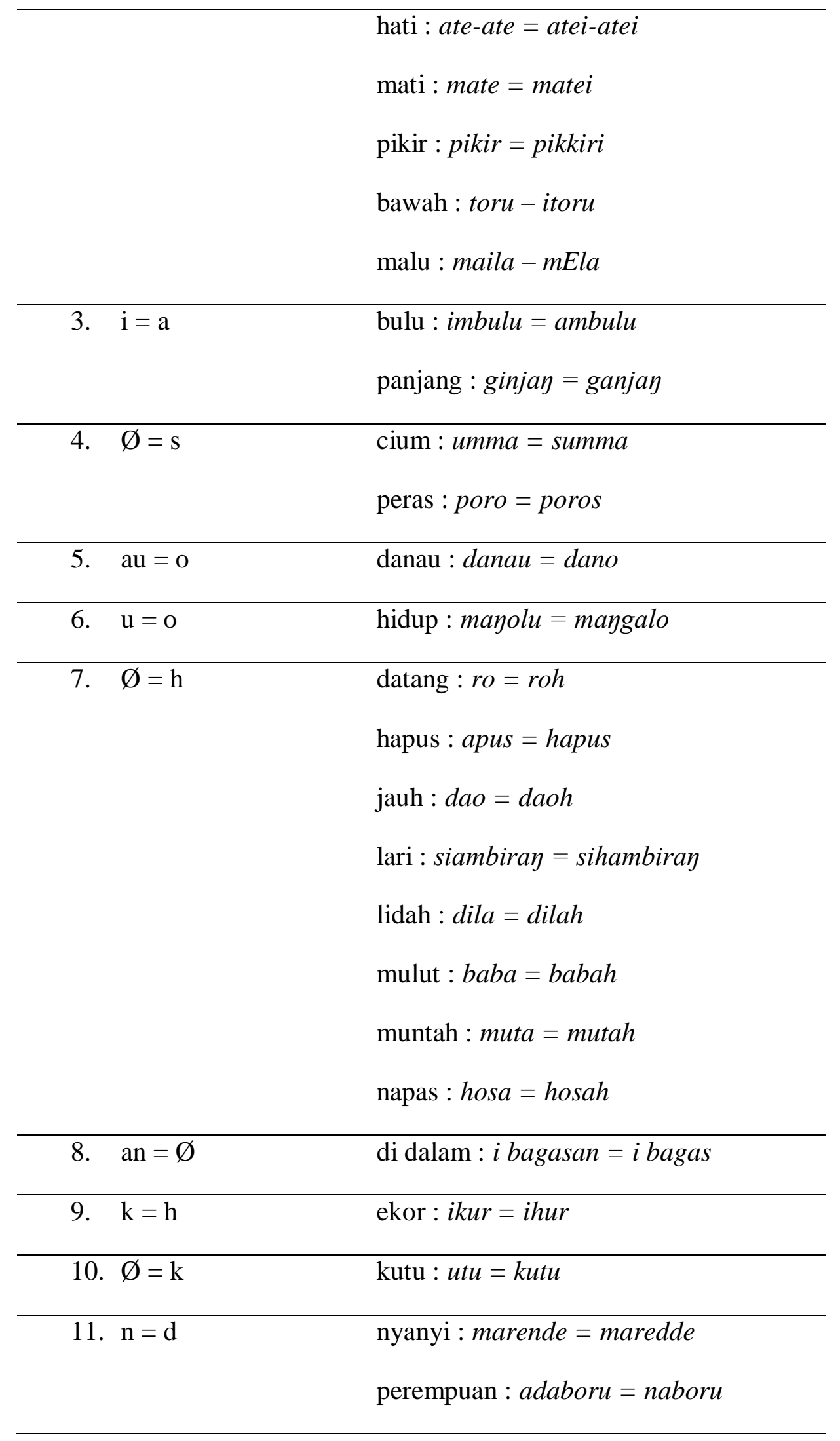

Kosakata berkorespondensi fonemis Bahasa Angkoa dan Bahasa Toba diketahui sebanyak 18 pasang kosakata. Beberapa koresfondensi fonemis yang terjadi antara BA dan BT adalah sebagai berikut: 
Tabel 5. Pasangan Berkorespondensi Fonemis pada BA dan BT

\begin{tabular}{|c|c|c|}
\hline No & Korespondensi & Kosakata \\
\hline 1. & $\varnothing=\mathrm{h}$ & $\begin{array}{l}\text { aku : au =ahu } \\
\text { bunuh : } \text { bunu = munuh } \\
\text { cuci : } \text { basuh = basu } \\
\text { kiri : ambiray = hambiray } \\
\text { lidah : dila = dilah }\end{array}$ \\
\hline 2. & $\varnothing=$ an & $\begin{array}{l}\text { anak }: \text { anak = anakkan } \\
\text { di dalam }: \text { i bagasan }=i \text { bagas }\end{array}$ \\
\hline 3. & $\mathrm{~h}=\mathrm{k}$ & $\begin{array}{l}\text { ekor : ikur }=\text { ihur } \\
\text { kering : koriy }=\text { horiy } \\
\text { tebal : kapal = hapal } \\
\text { ikan : ikan = ihan }\end{array}$ \\
\hline 4. & $\mathrm{a}=\mathrm{i}$ & $\begin{array}{l}\text { bulu }: \text { ambulu }=\text { imbulu } \\
\text { kuku }: \text { sasilon }=\text { sisilon } \\
\text { panjang }: \text { ginjay = ganjay }\end{array}$ \\
\hline 5. & $\varnothing=\mathrm{i}$ & $\begin{array}{l}\text { pikir : pikir }=\text { pikkiri } \\
\text { malu }: \text { maila }=\text { malu }\end{array}$ \\
\hline 6. & $\varnothing=\eta$ & $\begin{array}{l}\text { punggung : tayguru }= \\
\text { tayguruy } \\
\text { buka : buka = buyka }\end{array}$ \\
\hline
\end{tabular}

Selanjutnya terdapat 28 pasang kata yang berkorespondensi fonemis pada Bahasa Simalungun dan Bahasa Toba. Beberapa korespondensi fonemis yang terjadi adalah sebagai berikut: 
Tabel 6. Analisis Korespondensi Fonemis pada Bahasa Simalungun dan Bahasa Toba

\begin{tabular}{|c|c|}
\hline No $\quad$ Korespondensi & Kosakata \\
\hline 1. $\varnothing=\mathrm{h}$ & $\begin{array}{l}\text { aku : } a u=a h u \\
\text { datang : } r o h=r o \\
\text { hitung : } h E t o \eta=\text { Etoy } \\
\text { jatuh : } \text { madabu = madabuh } \\
\text { jauh : daoh = dao } \\
\text { mulut }: \text { babah }=\text { baba }\end{array}$ \\
\hline 2. $\varnothing=$ an & anak $:$ anak $=$ anakkan \\
\hline 3. $\varnothing=u$ & api $:$ apui $=$ api \\
\hline 4. $\quad \varnothing=\mathrm{m}$ & belah : mambola $=$ mabola \\
\hline 5. $\quad \varnothing=\mathrm{i}$ & $\begin{array}{l}\text { berenang }: \text { marlayei }=\text { marlaye } \\
\text { pikir }: \text { pikkiri }=\text { pikir } \\
\text { bawah }: \text { itoru }=\text { toru }\end{array}$ \\
\hline 6. $\quad b=m$ & $\begin{array}{l}\text { bunuh }: \text { bunu }=\text { munuh } \\
\text { tiup }: \text { obbus }=\text { ombus }\end{array}$ \\
\hline 7. $\varnothing=s$ & cium $:$ sium $=$ cium \\
\hline 8. $\quad \varnothing=\mathrm{d}$ & di mana : di dia $=i$ dia \\
\hline 9. $\varnothing=$ na & $\begin{array}{l}\text { hijau }: \text { naratan }=\text { rata } \\
\text { kami }: \text { hanami }=\text { hami } \\
\text { perempuan }: \text { naboru }=\text { borua }\end{array}$ \\
\hline 10. $\mathrm{i}=\mathrm{a}$ & $\begin{array}{l}\text { hitam : biroy = baroy } \\
\text { bulu }: \text { ambulu }=\text { imbulu }\end{array}$ \\
\hline 11. $\varnothing=\mathrm{k}$ & $\begin{array}{l}\text { ikat }: i k a t=i k k a t \\
\text { tembak }: t E b b a=t E m b a k\end{array}$ \\
\hline 12. $\mathrm{o}=\mathrm{u}$ & peras $:$ porus $=$ poros \\
\hline
\end{tabular}




\begin{tabular}{|c|c|}
\hline & telur $:$ tolur $=$ tolor \\
\hline \multirow[t]{2}{*}{ 13. $\mathrm{k}=\mathrm{h}$} & kutu : kutu=hutuy \\
\hline & kambing : kabbiy $=$ hambiy \\
\hline 14. $\varnothing=\eta$ & buka : buka = buyka \\
\hline
\end{tabular}

\section{Pasangan Kata Mirip Secara Fonetis}

Pasangan kata yang memiliki kemiripan secara fonetis artinya pasangan kata tersebut memiliki ciri-ciri fonetis yang cukup serupa sehingga dapat dianggap sebagai alofon. Adapun data pasangan yang mirip secara fonetis sebagai berikut:

Berdasarkan analisis data diketahui bahwa jumlah pasangan kata yang mirip secara fonetis terdapat 5 buah pasang kata. Perbedaan fonetis itu terjadi pada:

- Glos /pendek/ pada BA /pEndEk/ dan pada BS /pondokt/. Ciri artikulatoris yang dianggap cukup serupa sebagai alofon adalah /E/ dan /o/. Berdasarkan cara artikulasi dan daerah artikulasi, vokal /E/ dan /o/ merupakan vokal yang sama-sama menduduki bagian lidah yang sedang. Hanya saja vokal /E/ berada di depan lidah dan vokal /o/ berada di bagian lidah yang belakang.

- Glos /ular/ pada BA /ulok/ dan pada BS /ulog/, memiliki kesamaan fonetis pada fonem $/ \mathrm{k} /$ dan /g/. Ciri artikulatoris ini dianggap cukup serupa karena berdasarkan cara artikulasi dan daerah artikulasinya fonem-fonem ini merupakan konsonan hambat velar yang dihasilkan dengan menempelkan belakang lidah pada langit-langit lunak. Udara dihambat di sini dan kemudian dilepaskan.

- Glos /sempit/ pada BA /soppit/ dan pada BS /sompit/, memiliki kesamaan fonetis pada fonem $/ \mathrm{p} /$ dan $/ \mathrm{m} /$. Ciri artikulatoris ini dianggap cukup serupa karena berdasarkan cara artikulasi dan daerah artikulasinya fonem-fonem ini merupakan konsonan $/ \mathrm{p} / \mathrm{dan} / \mathrm{m} /$ merupakan konsonan bilabial yang dilafalkan dengan bibir atas dan bibir bawah terkatup rapat sehingga udara dari paru-paru tertahan untuk sementara waktu sebelum katupan itu dilepaskan.

- Glos /manEkoy/pada BA /ulok/ dan pada BS /manikuy/, memiliki kesamaan fonetis pada fonem /E/ dan /i/. Ciri artikulatoris ini dianggap cukup serupa karena berdasarkan cara artikulasi dan daerah artikulasinya fonem-fonem ini merupakan fonem vokal yang sama-sama menduduki wilayah bagian depan lidah.

- Glos /bege/ pada BA /ulok/ dan pada BS /bogei/, memiliki kesamaan fonetis pada fonem /e/ dan /o/. Ciri artikulatoris ini dianggap cukup serupa karena berdasarkan cara artikulasi dan daerah artikulasinya fonem-fonem ini merupakan fonem vokal yang sama-sama menempati bagian tengah lidah. 
Tabel 7. Pasangan Kata yang Mirip Secara Fonetis pada Bahasa Angkola dan Bahasa Toba

\begin{tabular}{llll}
\hline No & Bahasa Angkola & Bahasa Toba & Glos \\
\hline 1. & poro & poru & peras \\
\hline 2. & nipis & tipis & tipis \\
\hline 3. & tEmbak & tEbbak & tembak \\
\hline 4. & bolah & bolah & membelah \\
\hline
\end{tabular}

Dari tabel di atas dapat dilihat bahwa terdapat 4 buah pasang kata yang mirip secara fonetis pada Bahasa Angkola dan Bahasa Toba. Adapun perbedaan itu terdapat pada:

- Glos /peras/ pada BA /poro/ dan pada BS /poru/. Ciri artikulatoris yang dianggap cukup serupa sebagai alofon adalah /o/ dan /u/. Berdasarkan cara artikulasi dan daerah artikulasi, vokal /u/ dan /o/ sama-sama terletak pada bagian belakang lidah. Hanya saja vokal/u/ tinggi-belakang, sedangkan vokal/o/ sedang-belakang.

- Glos /tipis/ pada BA /nipis/ dan pada BT /tipis/. Ciri artikulatoris yang dianggap cukup serupa sebagai alofon adalah /E/ dan /o/. Berdasarkan cara artikulasi dan daerah artikulasi, konsonan /n/ dan /t/ merupakan konsonan alveolar yang dilafalkan dengan ujung lidah ditempelkan pada gusi. Namun konsonan /n/ merupakan konsonan hambat bersuara, sedangkan konsonan /t/ merupakan konsonan hambat tidak bersuara.

- Glos /tembak/ pada BA /tEmbak/ dan pada BT /tEbbak/. Ciri artikulatoris yang dianggap cukup serupa sebagai alofon adalah $/ \mathrm{m} /$ dan $/ \mathrm{b} /$. berdasarkan cara artikulasi dan daerah artikulasi, konsonan $/ \mathrm{m} /$ dan $/ \mathrm{b} /$ merupakan konsonan bilabial yang dilafalkan dengan bibir atas dan bibir bawah terkatup rapat sehingga udara dari paruapru tertahan untuk sementara waktu sebelum katupan itu dilepaskan.

- Glos /membelah/ pada BA /bolah/ dan pada BT /bolah/. Ciri artikulatoris yang dianggap cukup serupa sebagai alofon adalah /o/ dan /o/. berdasarkan cara artikulasi dan daerah artikulasi, fonem vokal /o/ dan /ə/ sama-sama menduduki bagian tengah lidah.

Tabel 8. Pasangan Kata yang Mirip Secara Fonetis pada Bahasa Simalungun dan Bahasa Toba

\begin{tabular}{llll}
\hline No & Bahasa Simalungun & Bahasa Toba & Glos \\
\hline 1. & $u \log$ & $u l o k$ & ular \\
\hline
\end{tabular}




2. bituha butuha usus

Berdasarkan tabel di atas, dapat dinyatakan bahwa terdapat 2 buah pasang kata yang mirip secara fonetis pada Bahasa Simalungun dan Bahasa Toba. Adapun perbedaan itu terdapat pada:

- Glos /ular/ pada BS /ulok/ dan pada BT /ulog/. Ciri artikulatoris yang dianggap cukup serupa sebagai alofon adalah /k/ dan /g/. Hal ini berdasarkan cara artikulasi dan daerah artikulasinya merupakan konsonan hambat velar yang dihasilkan dengan menempelkan belakang lidah pada langit-langit lunak. Udara dihambat di sini dan kemudian dilepaskan.

- Glos /usus/ pada BS /bituha/ dan pada BT /butuha/. Ciri artikulatoris yang dianggap cukup serupa sebagai alofon adalah /i/ dan /u/. Berdasarkan cara artikulasi dan daerah artikulasi, vokal /i/ dan /u/ merupakan vokal yang tinggi. Hanya saja vokal /i/ merupakan vokal tinggi-depan, sedangkan vokal/u/ merupakan vokal tinggi belakang.

\section{Pasangan Kata dengan Satu Fonem Beda}

Pasangan kata dengan satu fonem berbeda merupakan bila dalam satu pasangan terdapat perbedaan satu fonem. Hal ini terjadi karena pengaruh lingkungan yang dimasukinya, sedangkan dalam bahasa lain pengaruh lingkungan itu tidak mengubah fonemnya, serta memiliki ciri artikulatoris yang berbeda. Adapun data pasangan kata dengan satu fonem berbeda sebagai berikut:

Tabel 9. Pasangan Kata dengan Satu Fonem Beda pada Bahasa Angkola dan Bahasa Simalungun

\begin{tabular}{rlll}
\hline No & Bahasa Angkola & Bahasa Simalungun & Glos \\
\hline 1. & caciy & sasiy & cacing \\
\hline 2. & tusuk & nusuk & tikam \\
\hline 3. & roygur & loygur & kilat \\
\hline
\end{tabular}

Dari tabel tersebut, diketahui bahwa terdapat 3 pasang kosakata dengan satu fonem yang berbeda. Adapun perbedaan itu terjadi pada:

- Glos /cacing/ pada BA /caciy/dan pada BS /sasiy/. Perbedaan fonem pada glos tersebut terdapat pada fonem $/ c /$ dan fonem $/ s /$.

- Glos /kabut/ pada BA /tusuk/ dan pada BS /nusuk/. Perbedaan fonem pada glos tersebut terdapat pada fonem $/ t /$ dan fonem $/ n /$. 
- Glos /kilat/ pada BA /roygur/ dan pada BS /loygur/. Perbedaan fonem pada glos tersebut terdapat pada fonem $/ r /$ dan fonem $/ l /$

Tabel 10. Pasagan Kata dengan Satu Fonem Berbeda pada Bahasa Angkola dan Bahasa Toba

\begin{tabular}{llll}
\hline No & Bahasa Angkola & Bahasa Toba & Glos \\
\hline 1. & donok & jonok & dekat \\
\hline 2. & hulit & huliy & kulit \\
\hline 3. & martata & martaha & tertawa
\end{tabular}

Berdasarkan tabel di atas, dapat diketahui bahwa dalam kosakata satu fonem berbeda terdapat 3 buah pasang kosakata pada Bahasa Angkola dan Bahasa Toba. Adapun perbedaan itu terdapat pada:

- Glos /dekat/ pada BA /dohok/ dan pada BT /johok/. Perbedaan glos tersebut terdapat pada fonem $/ d /$ dan $/ j /$.

- Glos /kulit/ pada BA /hulit/ dan pada BT/huliy/. Perbedaan glos tersebut terdapat pada fonem $/ h /$ dan fonem $/ \eta /$.

- Glos /tertawa/ pada BA /martata/ dan pada BT /martaha/. Perbedaan glos tersebut terdapat pada fonem $/ t /$ dan fonem $/ h /$.

Tabel 11. Pasangan Kata dengan Satu Fonem Beda pada Bahasa Simalungun dan Bahasa Toba

\begin{tabular}{llll}
\hline No & Bahasa Simalungun & Bahasa Toba & Glos \\
\hline 1. & hulit & huliy & kulit \\
\hline 2. & ijur & tijur & ludah \\
\hline 3. & majol & majal & tumpul \\
\hline 4. & mEla & Malu & malu \\
\hline
\end{tabular}

Berdasarkan tabel di atas, dapat dinyatakan bahwa pada Bahasa Simalungun dan Bahasa Toba terdaapat 5 buah pasang kosakata yang memiliki satu fonem berbeda. Perbedaan itu terdapat pada: 
- Glos /kulit/ pada BS /hulit/ dan pada BT /huliy/. Perbedaan glos tersebut terdapat pada fonem $/ t /$ dan fonem $/ \eta /$.

- Glos /ludah/ pada BS /lijur/ dan pada BT /tijur/. Perbedaan glos tersebut terdapat pada fonem $/ /$ dan fonem $/ t /$.

- Glos /tongkat/ pada BS /tukkat/ dan pada BT /takkat/. Perbedaan glos tersebut terdapat pada fonem $/ o /$ dan $/ u /$.

- Glos /tumpul/ pada BS /majol/ dan pada BT /majal/. Perbedaan glos tersebut terdapat pada fonem $/ u /$ dan fonem $/ o /$.

- Glos /malu/ pada BS /mEla/ dan pada BT /malu/. Perbedaan glos tersebut terdapat pada fonem $/ E /$ dan fonem $/ a \backslash$

\section{E. KESIMPULAN}

Kekerabatan antara BA dan BS ditentukan berdasarkan penetapan kata kerabat, terdapat 85 pasangan identik, 30 pasangan berkorespondensi fonemis, 5 pasangan mirip secara fonetik, dan 3 pasangan dengan satu fonem berbeda. Maka total keseluruhan kata berkerabat antara BA dan BS adalah 123 kosakata dan terdapat 74 kosakata yang tidak berkerabat. Dalam BA dan BS, dari 197 pasangan kata terdapat 123 pasang kata yang berkerabat atau sebesar 62\%. Bahasa Angkola dan bahasa Simalungun mulai berpisah dari suatu bahasa proto antara 505-105 sebelum Masehi (dihitung dari tahun 2019). Kekerabatan antara BA dan BT ditentukan berdasarkan penetapan kata kerabat, terdapat 106 pasangan identik, 18 pasangan berkorespondensi fonemis, 4 pasangan mirip secara fonetik, dan 3 pasangan dengan satu fonem berbeda. Maka total keseluruhan kata berkerabat antara BA dan BT adalah 131 kosakata dan terdapat 66 kosakata yang tidak berkerabat. Dalam BA dan BT, dari 197 pasangan kata terdapat 131 pasang kata yang berkerabat atau sebesar 66\%. Bahasa Angkola dan bahasa Toba mulai berpisah dari suatu bahasa proto antara 505-105 sebelum Masehi (dihitung dari tahun 2019). Kekerabatan antara BS dan BT ditentukan berdasarkan penetapan kata kerabat, terdapat 78 pasangan identik, 28 pasangan berkorespondensi fonemis, 2 pasangan mirip secara fonetik, dan 5 pasangan dengan satu fonem berbeda. Maka total keseluruhan kata berkerabat antara BS dan BT adalah 93 kosakata dan terdapat 104 kosakata yang tidak berkerabat. Dalam BS dan BT, dari 197 pasangan kata terdapat 93 pasang kata yang berkerabat atau sebesar $47 \%$. Bahasa Simalungun dan Bahasa Toba mulai berpisah dari suatu bahasa proto antara 526-126 sebelum Masehi (dihitung dari tahun 2019).

\section{F. SARAN}

Kajian mengenai kekerabatan bahasa Angkola, bahasa Simalungun dan bahasa Toba serta pewarisan fonem vokal protobahasa austronesia ketiga bahasa tersebut sangat perlu dibaca oleh pemerhati bahasa, terutama pada orang yang baginya ketiga bahasa tersebut tidak 
menjadi bahasa ibu atau bahasa pertamanya. Di samping itu, tidak tertutup kemungkinan bagi mereka untuk mengkritik hasil penelitian ini dan menyajikan kajian yang berbeda dari hasil penelitian ini. Jika hal itu dapat terjadi, maka kajian mengenai penetapan kata kerabat serta pewarisan fonem vokal protobahasa austronesia dalam ketiga bahasa tersebut akan semakin luas dan semakin berkembang.

\section{DAFTAR PUSTAKA}

Al-Khuli, Muhammad Ali. 1982. A Dictionary Of Theoretical Linguistics. Beirut : Librairie du Liban.

Bellwood, Peter dan James J. Fox, Darrell Tryon dkk. 1995. The Austronesians : Historical and Comparative Perspectives. Canberra : Australian National University.

Blust, Robert. 2013. The Austronesian Language. Australia : Australian National University.

Campbell, Lyle. 1999. Historical Linguistics an Introduction. Edinburgh : Edinburgh University Press.

Crowley, Terry. 2010. An Introduction to Historical Linguistics. Melbourne : Oxford University Press

Fernandez, Inyo Yos. 1996. Relasi Historis Kekerabatan Bahasa Flores : NTT. Nusa Indah.

Fitra, Y., \& Afria, R. (2017). Kekerabatan Bahasa-Bahasa Etnis Melayu, Batak, Sunda, Bugis, dan Jawa Di Provinsi Jambi: Sebuah Kajian Linguistik Historis Komparatif. Jurnal Titian, $\quad l(2)$, 204-2018. Retrieved from https://online-journal.unja.ac.id/titian/article/view/4228/3012

Hanna, Mursidin, \& Jannah, S. N. R. (2018). Language Kinship between Tulambatu and Tolaki Language in North Konawe. Mediterranean Journal of Social Sciences, 9(1), 91-102. https://doi.org/10.2478/mjss-2018-0009

Hutabarat, F. M., Ermanto, E., \& Juita, N. 2013. Kekerabatan Bahasa Batak Toba Dengan Bahasa Batak Mandailing. Jurnal Bahasa Dan Sastra UNP, 2(1), 1-13. https://doi.org/https://doi.org/10.24036/822820

Keraf, Gorys. 1984. Linguistik Bandingan Historis. Jakarta : Gramedia Pustaka Utama.

Kridalaksana, Harimurti. 2008. Kamus Linguistik. Jakarta : Gramedia.

Maulita, Gokma. 2015. "Kekerabatan Bahasa Batak Toba dan Bahasa Batak Angkola Suatu Kajian Linguistik Historis Komparatif'. Jurnal Arkhais. Vol 6 (1): 46-52.

Mbete, Aron Meko. 2016. Fitur-Fitur Subkelompok dam Beberapa Bahasa di Indonesia Jejak Proses Migrasi Austronesia. di dalam : Seminar Internasional Migrasi Austronesia; Jakarta: 14-17 September 2016. Jakarta : Badan 
Panggabean, H. (2012). Analisis Leksikostatistik Terhadap Bahasa Toba, Bahasa Angkola, dan Bahasa Karo. Majalah Ilmiah Methoda, 2(1), 63-71. Retrieved from http://ojs.lppmmethodistmedan.net/index.php/METHODA/article/view/26/26.

Pengembangan dan Pembinaan Bahasa, Kementrian Pendidikan dan Kebudayaan.

Robins, R.H.. 1990. A Short History of Linguistics. London dan Newyork: Longman.

Sudaryanto. 2016. Metode dan Teknik Analisis Bahasa. Yogyakarta Duta Wacana University Press. 